\title{
$\mathrm{A} \mathrm{C} \mathrm{G}^{-}$ publications
}

Org. Commun. 12:2 (2019) 101-108

organic communications

\section{Oxidation of hesperidin into diosmin using ionic liquids}

\author{
V. Thanh Nguyen $\odot$, T. Kim-Chi Huynh $\odot$, \\ Thanh-Danh Nguyen and T. Kim-Dung Hoang $\odot^{*}$ \\ Institute of Chemical Technology, Vietnam Academy of Science and Technology, \\ 01 Mac Dinh Chi Street, District 1, Ho Chi Minh City, Vietnam
}

(Received April 16, 2019; Revised May 22, 2019 ; Accepted May 23, 2019)

\begin{abstract}
In this study, ionic liquids (ILs) were used as green solvents for the conversion of hesperidin into diosmin for the first time. Specifically, diosmin was synthesized via the oxidation of hesperidin with iodine in Ils

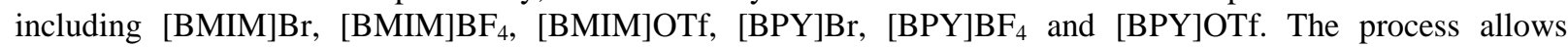
obtaining diosmin with high yields of $79-85 \%$, in which, $[\mathrm{BPY}] \mathrm{Br}$ and $[\mathrm{BPY}] \mathrm{BF}_{4}$ exhibited excellent solvent properties for the oxidation of hesperidin even after several recycling cycles. Furthermore, it was found that the presence of water in recycle ILs from 1-5\% (v/v) induced a significant increase in diosmin yields.
\end{abstract}

Keywords: Diosmin; oxidation; hesperidin; synthesis; ionic liquid. @ 2019 ACG Publication. All right reserved.

\section{Introduction}

Hesperidin, a flavanone glycoside, is abundantly found in many citrus fruits and isolated from citrus peel by Lebreton et al. ${ }^{1}$ Hesperidin has displayed a wide variety of biological activities such as anti-inflammatory, anti-carcinogen, antiviral, anti-allergy, antifungal activities and neuroprotective effect, thus it is also called as a bioflavonoid. ${ }^{2-6}$ In addition, intake of hesperidin is shown to have various health benefits, especially against vascular diseases, thus hesperidin supplement has been effectively used to treat blood vessel disorders. ${ }^{7}$ In some pharmacokinetic researches of hesperidin, its interaction with some drugs including diltiazem (calcium channel blocker, antiarrhythmic), fexofenadine (antihistamine) and verapamil (mitotic inhibitor, anticancer), along with mechanism of side effects have been discussed. ${ }^{8}$ Recently, hesperidin has been applied as a crude material for conversion of diosmin, which was applied commonly to treat chronic venous insufficiency. ${ }^{9}$

Diosmin (3',5,7-trihydroxy-4'-methoxyflavone 7-rutinoside) was first isolated from hyssop plants by Oesterle and Wander and is well-known as a therapeutic agent since $1969 .{ }^{10}$ Diosmin is considered to be vascular-protecting agent, and widely used to treat varicose veins and hemorrhoids. As a flavonoid, diosmin has various biological properties including anti-inflammatory, antioxidant and antimutagenic activities ${ }^{11}$, and is shown to have anti-hyperlipidemic effects in clinical research on isoproterenol induced myocardial infarcted rats. ${ }^{12}$ Diosmin-containing flavonoid mixture has been indicated to improve factors that associated with diabetic complications before and after the

\footnotetext{
*Corresponding author: E-mail: htkdung@ict.vast.vn; hoangthikimdung@gmail.com
} 
intervention. ${ }^{13} \mathrm{~A}$ recent study on diabetic rats orally treated with a complexation of zinc ions and diosmin at a concentration of $20 \mathrm{mg} / \mathrm{kg}$ b.w./rat/ day for 30 days, showed that the complexation can be used to efficiently treat diabetes mellitus as an anti-hyperglycemic agent. ${ }^{14}$

Due to diosmin's pharmaceutical importance, the improvement of its synthesis process has been extensively researched in recent years. It was synthesized by using $\mathrm{N}$-bromosuccinimide for the bromination of acetyl hesperidin in the presence of benzoyl peroxide in chloroform and obtained 44\%yield. ${ }^{15}$ In another report, hesperidin was treated with aqueous sodium hydroxide in the presence of iodine and pyridine at $100^{\circ} \mathrm{C}$ to obtain diosmin with a yield of $66 \%{ }^{16}$ In connection with our ongoing research program, involving the investigation of synthesis and bioactivity evaluation of flavonoids ${ }^{18-19}$, diosmin was shown to be an important intermediate in the synthesis of novel bioactive compounds, hence facile synthesis of diosmin is a key step to approach specific bioactive compounds. One of the main challenges in diosmin preparation is to acquire the product with low content of bromine or iodine intermediates or by-products formed during the process. The elimination of these compounds typically required a large quantity of organic solvents, which are not economic and environmentally friendly. Despite that, most proposed methods for synthesizing diosmin still rely on different organic solvents, very few results have been achieved in green synthesis of diosmin so far. Alternative green solvents for organic synthesis are ionic liquids (ILs). They offer unique benefit over organic solvents in organic synthesis including negligible vapor pressure, high in conductivity, thermal stability, and reusability. ${ }^{17}$ However, the use of ILs has not yet been implemented in diosmin synthesis.

In this paper, we report a novel green method for diosmin synthesis using ILs. Specifically, diosmin is synthesized from hesperidin using iodine as an oxidant in various ILs, including 1-butyl-3methylimidazolium bromide [BMIM]Br, 1-butyl-3-methylimidazolium tetrafluoroborate [BMIM] $\mathrm{BF}_{4}$, 1-butyl-3-methylimidazolium triflomethansufornate [BMIM]OTf, n-butyl-pyridinium bromide $[\mathrm{BPY}] \mathrm{Br}, \quad \mathrm{n}$-butyl-pyridinium tetrafluoroborate $\left[\mathrm{BPY}^{\mathrm{B}} \mathrm{BF}_{4}\right.$ and n-butyl-pyridinium trifloromethansunfonate [BPY]OTf. The efficient of ILs in the synthesis process was compared with traditional organic solvent pyridine from the previous study. ${ }^{20}$ The use of recycled ILs for diosmin synthesis was also investigated, especially, on the influence of water concentration during the recycling process.

\section{Experimental}

\subsection{General information}

All reagents were purchased from Merck (Germany) and Acros (Belgium). The solvents were provided by Xilong (China) and Chemsol (Vietnam) and used as received. All the synthesized compounds were characterized by ${ }^{1} \mathrm{H}$ and ${ }^{13} \mathrm{C}$ NMR spectroscopy in DMSO (Bruker AMO FT-NMR Spectrometer), and HRMS (Bruker MicroOTOF-Q). The yields of diosmin synthesized with different ILs were determined by HPLC analyses using C18 column ( $250 \mathrm{~mm}$ x $4.6 \mathrm{~mm}$ i.d., $5 \mu \mathrm{m}$ particle size).

\subsection{General procedure for the synthesis of ionic liquids}

A mixture of 1-methylimidazole $(20 \mathrm{~mL}, 376.8 \mathrm{mmol})$ or pyridine $(20 \mathrm{~mL}, 278.1 \mathrm{mmol})$ and butyl bromide ( $30 \mathrm{~mL}, 416.4 \mathrm{mmol}$ ) was heated under microwave irradiation for a pre-determined time. After the reaction was completed, the mixture was separated into two layers. The crude product has a bright yellow color and was extracted from the solution washed subsequently with ethyl acetate $(3 \times 15$ $\mathrm{mL})$ and diethyl ether $(3 \times 15 \mathrm{~mL})$. Finally, the resulting liquid was dried under reduced pressure to eliminate the remaining solvent. The obtained Ils, n-butyl-pyridinium bromide [BPY]Br and 1-butyl-3methylimidazolium bromide [Bmim]Br, were a pale -yellow liquid.

n-butyl-pyridinium bromide [BPY]Br (1): ${ }^{1} \mathrm{H}-\mathrm{NMR}\left(500 \mathrm{MHz}, \mathrm{DMSO}-\mathrm{d}_{6}, \delta\right): 9.22-9.23\left(\mathrm{~d}, 2 \mathrm{H}, \mathrm{H}_{2}\right.$ and $\left.\mathrm{H}_{6}, \mathrm{~J}=5.5 \mathrm{~Hz}\right), 8.17-8.20\left(\mathrm{t}, 2 \mathrm{H}, \mathrm{H}_{3}\right.$ and $\left.\mathrm{H}_{5}, \mathrm{~J}=7 \mathrm{~Hz}\right), 8.65\left(\mathrm{t}, 1 \mathrm{H}, \mathrm{H}_{4}, \mathrm{~J}=7.75 \mathrm{~Hz}\right), 4.70\left(\mathrm{t}, 2 \mathrm{H}, \mathrm{H}_{7}\right), 1.92$ (quint, $2 \mathrm{H}, \mathrm{H}_{8}$ ), 1.31 (sext, $2 \mathrm{H}, \mathrm{H}_{9}$ ), 0.90 (t, 3H, $\mathrm{H}_{10}$ ); ${ }^{1} \mathrm{C}-\mathrm{NMR}\left(125 \mathrm{MHz}, \mathrm{DMSO}-\mathrm{d}_{6}, \delta \mathrm{ppm}\right.$ ): 144.71 $\left(\mathrm{C}_{2}, \mathrm{C}_{6}\right), 128.00\left(\mathrm{C}_{3}, \mathrm{C}_{5}\right), 145.44\left(\mathrm{C}_{4}\right), 60.30\left(\mathrm{C}_{7}\right), 32.62\left(\mathrm{C}_{8}\right), 18.63\left(\mathrm{C}_{9}\right), 13.25\left(\mathrm{C}_{10}\right)$; HRMS: calcd. for peak cation [BPY]Br : $136.1129 \mathrm{~g} / \mathrm{mol}$, found: 136.112075 . 
1-butyl-3-methylimidazolium bromide [Bmim]Br (2) : ${ }^{1} \mathrm{H}-\mathrm{NMR}\left(500 \mathrm{MHz}, \mathrm{DMSO}-\mathrm{d}_{6}, \delta\right): 9.31(\mathrm{~s}, 1 \mathrm{H}$, $\left.\mathrm{H}_{2}\right), 7.84\left(\mathrm{~d}, 1 \mathrm{H}, \mathrm{H}_{4}, \mathrm{~J}=1.5 \mathrm{~Hz}\right), 7.76\left(\mathrm{~d}, 1 \mathrm{H}, \mathrm{H}_{5}, \mathrm{~J}=1.5 \mathrm{~Hz}\right), 4.20\left(\mathrm{t}, 2 \mathrm{H}, \mathrm{H}_{7}\right), 3.87\left(\mathrm{~s}, 3 \mathrm{H}, \mathrm{H}_{6}\right), 1.27$ (sext, 2H, $\mathrm{H}_{9}$ ), 1.79 (quint, 2H, $\mathrm{H}_{8}$ ), 0.89 (t, 3H, $\left.\mathrm{H}_{10}\right) ;{ }^{13} \mathrm{C}-\mathrm{NMR}\left(125 \mathrm{MHz}\right.$, DMSO - $\mathrm{d}_{6}, \delta \mathrm{ppm}$ ): $136.45\left(\mathrm{C}_{2}\right), 123.48\left(\mathrm{C}_{4}\right), 122.19\left(\mathrm{C}_{5}\right), 48.38\left(\mathrm{C}_{7}\right), 35.71\left(\mathrm{C}_{6}\right), 31.30\left(\mathrm{C}_{8}\right), 18.67\left(\mathrm{C}_{9}\right), 13.20\left(\mathrm{C}_{10}\right)$; HRMS: calcd. for peak cation [Bmim]Br: $139.1239 \mathrm{~g} / \mathrm{mol}$, found: 139.122975 .

$5 \mathrm{~mL}$ butyl-3-methylimidazolium bromide (or butyl-pyridinium bromide) and $\mathrm{M}^{+} \mathrm{Y}^{-}$salts $\left(\mathrm{NaBF}_{4}\right.$ or KOTf) were mixed together. Water was then added in the required amount to dissolve the starting materials. This mixture was microwave irradiated at the appropriate temperature and time. After the reaction was complete, it was cool down to room temperature, from which water residue was removed under reduced pressure. $10 \mathrm{~mL} \mathrm{CH} \mathrm{Cl}_{2}$ was then added to the mixture and kept refrigerated overnight. The resulting solids were separated by filtration.

n-butyl-pyridinium tetrafluoroborate $[B P Y] B F_{4}(3)$ : orange liquid ${ }^{1} \mathrm{H}-\mathrm{NMR}\left(500 \mathrm{MHz}\right.$, DMSO- $\left.\mathrm{d}_{6}, \delta\right)$ : 9.12-9.13(d, 2H, $\mathrm{H}_{2}$ and $\left.\mathrm{H}_{6}, \mathrm{~J}=5.5 \mathrm{~Hz}\right), 8.14-8.17\left(\mathrm{t}, 2 \mathrm{H}, \mathrm{H}_{3}\right.$ and $\left.\mathrm{H}_{5}, \mathrm{~J}=7 \mathrm{~Hz}\right), 8.62\left(\mathrm{~m}, 1 \mathrm{H}, \mathrm{H}_{4}, \mathrm{~J}=2.25 \mathrm{~Hz}\right)$, 4.65(t, 2H, $\left.\mathrm{H}_{7}\right), 1.93$ (quint, $\left.2 \mathrm{H}, \mathrm{H}_{8}\right), 1.30\left(\mathrm{sext}, 2 \mathrm{H}, \mathrm{H}_{9}\right), 0.91\left(\mathrm{t}, 3 \mathrm{H}, \mathrm{H}_{10}\right) ;{ }^{13} \mathrm{C}-\mathrm{NMR}(125 \mathrm{MHz}, \mathrm{DMSO}-$ $\left.\mathrm{d}_{6}, \delta \mathrm{ppm}\right): 144.70\left(\mathrm{C}_{2}, \mathrm{C}_{6}\right), 128.09\left(\mathrm{C}_{3}, \mathrm{C}_{5}\right), 145.49\left(\mathrm{C}_{4}\right), 60.57\left(\mathrm{C}_{7}\right), 32.64\left(\mathrm{C}_{8}\right), 18.72\left(\mathrm{C}_{9}\right), 13.27\left(\mathrm{C}_{10}\right)$; HRMS: calcd. for peak cation [BPY]BF $4: 136.1133 \mathrm{~g} / \mathrm{mol}$, found: 139.112075.

n-butyl-pyridinium trifloromethansunfonate [BPY]Otf (4): yellow liquid ${ }^{1} \mathrm{H}-\mathrm{NMR}\left(500 \mathrm{MHz}, \mathrm{DMSO}-\mathrm{d}_{6}\right.$,

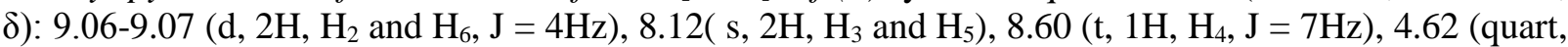
$\left.2 \mathrm{H}, \mathrm{H}_{7}\right), 1.90$ (t, 2H, $\left.\mathrm{H}_{8}\right), 1.29$ (tetra, $\left.2 \mathrm{H}, \mathrm{H}_{9}\right), 0.89$ (d, 3H, $\left.\mathrm{H}_{10}, \mathrm{~J}=7 \mathrm{~Hz}\right) ;{ }^{13} \mathrm{C}-\mathrm{NMR}(125 \mathrm{MHz}, \mathrm{DMSO}-$ $\left.\mathrm{d}_{6}, \delta \mathrm{ppm}\right): 144.83\left(\mathrm{C}_{2}\right.$ and $\left.\mathrm{C}_{6}\right), 145.72\left(\mathrm{C}_{4}\right), 60.96\left(\mathrm{C}_{7}\right), 32.84\left(\mathrm{C}_{8}\right), 18.94\left(\mathrm{C}_{9}\right), 13.44\left(\mathrm{C}_{10}\right)$; HRMS: calcd. for peak cation [BPY]OTf: $139.1159 \mathrm{~g} / \mathrm{mol}$, found: 139.112075 .

1-butyl-3-methylimidazolium tetrafluoroborate [Bmim]BF $4(5):{ }^{1} \mathrm{H}-\mathrm{NMR}\left(500 \mathrm{MHz}, \mathrm{DMSO}-d_{6}, \delta\right)$ : $9.16\left(\mathrm{~s}, 1 \mathrm{H}, \mathrm{H}_{2}\right), 7.77\left(\mathrm{~s}, 1 \mathrm{H}, \mathrm{H}_{4}\right), 7.70\left(\mathrm{~s}, 1 \mathrm{H}, \mathrm{H}_{5}\right), 4.18\left(\mathrm{t}, 2 \mathrm{H}, \mathrm{H}_{7}\right), 3.86\left(\mathrm{~d}, 3 \mathrm{H}, \mathrm{H}_{6},\right), 1.27$ (sext, $2 \mathrm{H}, \mathrm{H}_{9}$, $\mathrm{J}=7.5 \mathrm{~Hz}$ ), 1.78 (quint, $\left.2 \mathrm{H}, \mathrm{H}_{8}\right), 0.89\left(\mathrm{t}, 3 \mathrm{H}, \mathrm{H}_{10}\right) ;{ }^{1} \mathrm{H}-\mathrm{NMR}\left(500 \mathrm{MHz}, \mathrm{DMSO}-d_{6}, \delta \mathrm{ppm}\right): 9.16(\mathrm{~s}$, $\left.1 \mathrm{H}, \mathrm{H}_{2}\right), 7.77\left(\mathrm{~s}, 1 \mathrm{H}, \mathrm{H}_{4}\right), 7.70\left(\mathrm{~s}, 1 \mathrm{H}, \mathrm{H}_{5}\right), 4.18\left(\mathrm{t}, 2 \mathrm{H}, \mathrm{H}_{7}\right), 3.86\left(\mathrm{~d}, 3 \mathrm{H}, \mathrm{H}_{6}\right), 1.27$ (sext, $2 \mathrm{H}, \mathrm{H}_{9}, \mathrm{~J}=7.5$ $\mathrm{Hz}$ ), 1.78 (quint, $2 \mathrm{H}, \mathrm{H}_{8}$ ), 0.89 (t, 3H, $\mathrm{H}_{10}$ ); HRMS: calcd. for peak cation [Bmim] $\mathrm{BF}_{4}: 139.1238 \mathrm{~g} / \mathrm{mol}$, found: 139.122975 .

1-butyl-3-methylimidazolium trifluoromethansunfonate [Bmim]Otf (6): ${ }^{1} \mathrm{H}-\mathrm{NMR}(500 \mathrm{MHz}, \mathrm{DMSO}-$ $\left.d_{6}, \delta\right): 9.08\left(\mathrm{~s}, 1 \mathrm{H}, \mathrm{H}_{2}\right), 7.75\left(\mathrm{~s}, 1 \mathrm{H}, \mathrm{H}_{4}\right), 7.68\left(\mathrm{~s}, 1 \mathrm{H}, \mathrm{H}_{5}\right), 4.19\left(\mathrm{t}, 2 \mathrm{H}, \mathrm{H}_{7}\right), 3.85\left(\mathrm{~d}, 3 \mathrm{H}, \mathrm{H}_{6}\right), 1.28$ (sext, $2 \mathrm{H}, \mathrm{H}_{9}, \mathrm{~J}=7.38 \mathrm{~Hz}$ ), 1.79 (quint, $2 \mathrm{H}, \mathrm{H}_{8}, \mathrm{~J}=7.5 \mathrm{~Hz}$ ), 0.91 (t, 3H, $\left.\mathrm{H}_{10}\right) ;{ }^{13} \mathrm{C}-\mathrm{NMR}(125 \mathrm{MHz}$, DMSO $\left.d_{6}, \delta \mathrm{ppm}\right): 136.47\left(\mathrm{C}_{2}\right), 123.56\left(\mathrm{C}_{4}\right), 122.23\left(\mathrm{C}_{5}\right), 48.52\left(\mathrm{C}_{7}\right), 35.68\left(\mathrm{C}_{6}\right), 31.31\left(\mathrm{C}_{8}\right), 18.72\left(\mathrm{C}_{9}\right), 13.15$ $\left(\mathrm{C}_{10}\right)$; HRMS: calcd. for peak cation [Bmim]OTf: $139.1259 \mathrm{~g} / \mathrm{mol}$, found: 139.122975 .

\subsection{Procedure for the conversion of hesperidin to diosmin in pyridine and ionic liquids.}

The synthesis of diosmin in pyridine or ILs followed the same procedure. Specifically, hesperidin $(1 \mathrm{~g}, 1.64 \mathrm{mmol})$, pyridine/ILs $(7.0 \mathrm{~mL})$, iodine $(0.45 \mathrm{~g}, 1.78 \mathrm{mmol})$ and aqueous sodium hydroxide $(0.1 \mathrm{~g}, 2.50 \mathrm{mmol})$ was added together and reacted as described above and indicated in Table 1. The progress of the reaction was monitored by thin layer chromatography (TLC). After the reaction was complete, the mixture was left to solidify in an ice bath overnight. The resulting precipitate was filtered, washed with $\mathrm{H}_{2} \mathrm{O}$ and dried under reduced pressure. The obtained solid was then stirred in minimum amount $\mathrm{CH}_{3} \mathrm{OH}$ and refluxed for 2 hours, to which a saturated aqueous sodium thiosulfate solution was added to remove iodine. The final crude product was filtered and dried under reduced pressure.

3',5,7-trihydroxy-4'-methoxyflavone 7-rutinoside diosmin (7): white powder. ${ }^{1} \mathrm{H}-\mathrm{NMR}(500 \mathrm{MHz}$, DMSO-d6, $\delta): 3.87$ (s, 3H, -OCH3), $6.82\left(\mathrm{~s}, 1 \mathrm{H}, \mathrm{H}_{3}\right), 6.46$ (d, 1H, H6, J6-8 = 2), 6.76 (d, 1H, H8, J8-6 = 
$2 \mathrm{~Hz}), 7.44\left(\mathrm{~d}, 1 \mathrm{H}, \mathrm{H} 2^{\prime}, \mathrm{J} 2^{\prime}-6^{\prime}=2.5 \mathrm{~Hz}\right), 7.12\left(\mathrm{~d}, 1 \mathrm{H}, \mathrm{H} 5{ }^{\prime}, \mathrm{J} 5^{\prime}-6^{\prime}=8.5 \mathrm{~Hz}\right), 7.56\left(\mathrm{dd}, 1 \mathrm{H}, \mathrm{H} 66^{\prime}, \mathrm{J} 66^{\prime}-2^{\prime}=\right.$ 2.5, J6' -5'= 8.5 Hz), 12.92, $9.44\left(-\mathrm{OH}\left(5,3^{\prime}\right)\right) ;{ }^{13} \mathrm{C}-\mathrm{NMR}$ (125 MHz, DMSO-d6, $\delta$ ppm): 55.75 (-OCH3), $164.15\left(\mathrm{C}_{2}\right), 103.79\left(\mathrm{C}_{3}\right), 181.87\left(\mathrm{C}_{4}\right), 161.15\left(\mathrm{C}_{5}\right), 99.56\left(\mathrm{C}_{6}\right), 162.90\left(\mathrm{C}_{7}\right), 94.76\left(\mathrm{C}_{8}\right), 156.90\left(\mathrm{C}_{9}\right)$, ew105.40 $\left.\left(\mathrm{C}_{10}\right), 122.87\left(\mathrm{C}_{1}\right)^{\prime}\right), 113.12\left(\mathrm{C}_{2}\right), 146.74\left(\mathrm{C}_{3^{\prime}}\right), 151.27\left(\mathrm{C}_{4}{ }^{\prime}\right), 112.25\left(\mathrm{C}_{5}\right), 118.88\left(\mathrm{C}_{6^{\prime}}\right)$. Exact mass of molecular ion $m / z$ [M-H] $=607.1658$, calcd. for $\mathrm{C}_{28} \mathrm{H}_{32} \mathrm{O}_{15}: 607.1657$.

\subsection{Influence of water concentration in pyridine and ionic liquid on the synthesis of diosmin.}

Procedure for conversion was conducted as described above 2.3. The water content was calculated according to the percentage of solvents (pyridine and ILs), the percentage of which changed from $1 \%$ to $45 \%$ following the volume of solvents.

\section{Results and Discussion}

\subsection{Synthesis of ionic liquids}

The aim of this study is to improve the oxidation yield of hesperidin into diosmin using ILs, along with sustaining recyclable ability of the ILs. Therefore, the microwave-assisted preparation of ILs is a key step in the overall synthesis process of diosmin, allowed reducing reaction time and enhancing the reaction yield. The synthetic routes of ILs were depicted in Scheme 1.

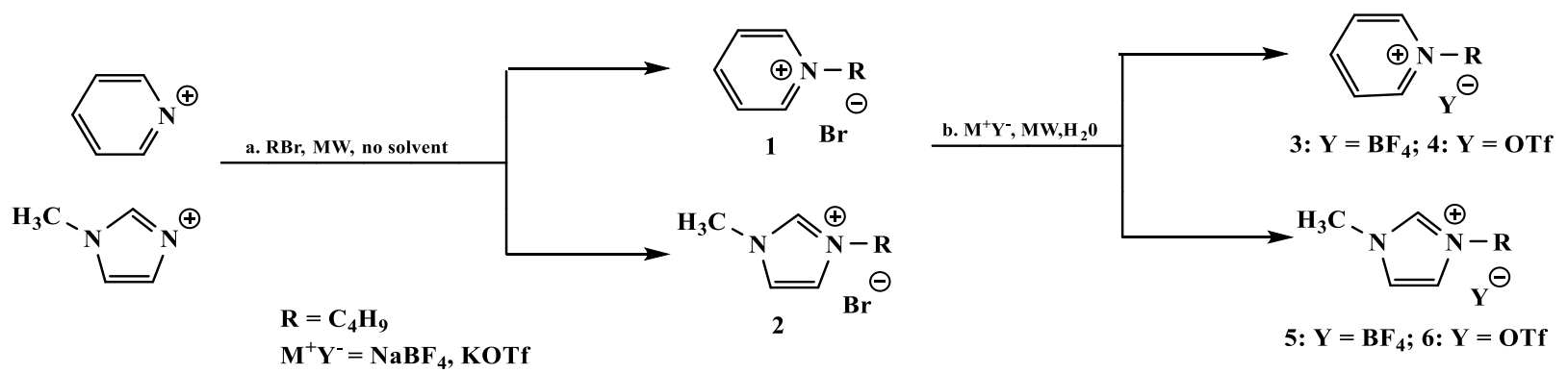

Scheme 1. Microwave-assisted synthesis of pyridinium and methylimidazolium derivatives based ionic liquids

The synthesis of ILs was performed via a two-step process. ${ }^{21}$ The first step involved the reaction of pyridine and methylimidazole with a large excess of alkyl halides to produce $\mathrm{N}$-alkylpyrinidium and $\mathrm{N}$-alkylmethylimidazole halides. In the second step, a simple substitution of the halides was carried out by functional anions. All reactions were conducted under microwave irradiation and the products were obtained in excellent yields (80-99\%) with short reaction time Figure 1.

In particular, the reaction speed of alkyl halides with [BMIM]Br is much faster than that of [BPY]Br. This could be due to the activating effect of the methyl group which increases the charge density in the imidazole ring, allowed the reaction to proceed faster in 2 minutes, than the pyridine ring in 15 minutes. However, the substitution reaction, performed by another anion in the last step, still required long reaction time, reaching 40 minutes for both $[\mathrm{BMIM}] \mathrm{BF}_{4}$ and [BMIM]OTf. This is because of the steric hindrance created by the approaching of larger size anions slowing down the reaction speed. Nevertheless, these anions provided better yields, especially with [BMIM]BF 4 and [BMIM]OTf 99\% and 95\%, respectively, as shown in Figure 1. 


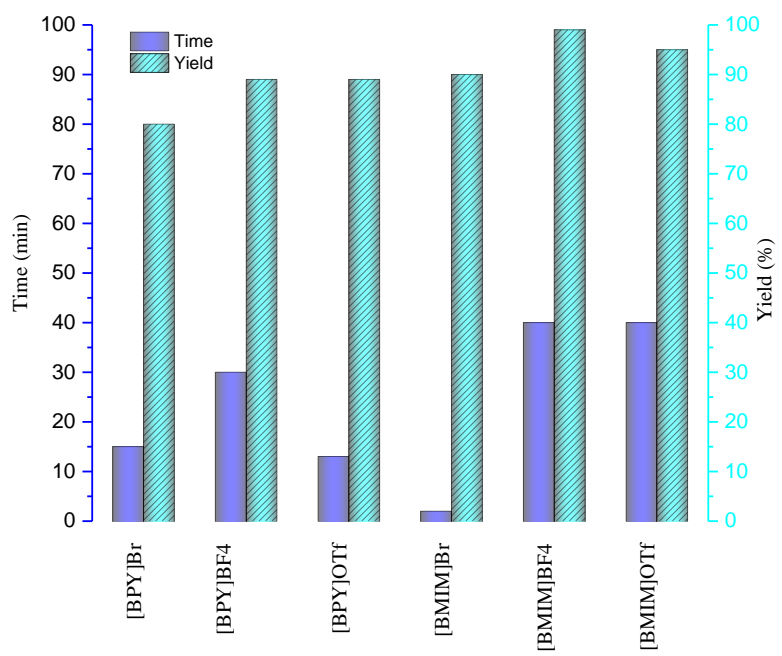

Figure 1. Reaction times and yields of the preparation process for different ILs

\subsection{Synthesis of diosmin}

To prevent the negative impact of organic waste on the environment and promote the development of green chemistry in diosmin synthesis, it is necessary to substitute the traditional organic medium pyridine with green medium ILs. Here, the preparation of diosmin in ILs and pyridine was performed in parallel for comparison. The synthesis of diosmin followed the chemical reaction shown in Figure 2. The beginning material, hesperidin was dissolved in pyridine or ILs after that iodine was added, then the amount of $\mathrm{NaOH}$ was put the mixture to promote the solubility of hesperidin. The effect of ILs on the oxidation of hesperidin was clearly shown by monitoring the reaction time with TLC, cutting the reaction time to half from 12 hours with pyridine to 6 hours. Simultaneously, the temperature required for the conversion of hesperidin to diosmin in ILs is lower than in pyridine, $68-70^{\circ} \mathrm{C}$, and $90^{\circ} \mathrm{C}$, respectively, as shown in Table 1 . Therefore, using ILs in the industrial manufacture of diosmin can be cost effective due to lower power consumption. The final product diosmin was crystallized in $\mathrm{H}_{2} \mathrm{O}: \mathrm{DMF}(2: 1 \mathrm{v} / \mathrm{v})$ mixture.
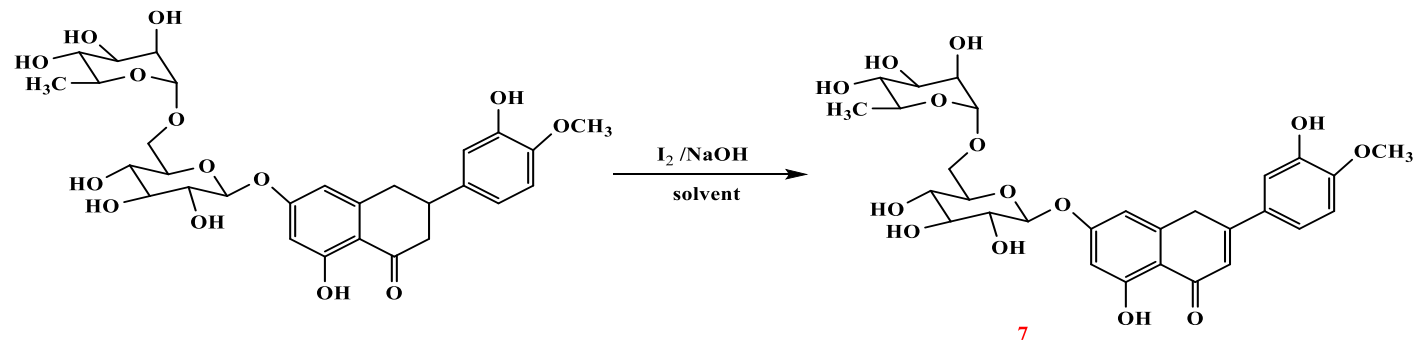

Figure 2. The reaction of conversion of hesperidin into diosmin

Overall, the reaction of conversion of hesperidin into diosmin using pyridine, pyridinium and methylimidazolium-based ILs, resulted in various yields of the products, as well as the changes in reaction time. In particular, diosmin gained $75 \%$ yield in pyridine as a solvent and this yield was increased when pyridine was removed by pyridinium -based ILs. However, the trend was not 
maintained in the presence of methylimidazolium -based ILs. The yield dropped sharply from $85 \%$ to $35 \%$. The best yield obtained by using $[\mathrm{BPY}] \mathrm{Br}$ and $[\mathrm{BPY}] \mathrm{BF}_{4}$ was as high as $85 \%$ which was determined by HPLC analysis. On the other hand, the conversion in imidazolium-based ILs gave a lower yield of $76 \%$.

The conversion in ILs provided higher yields than that of pyridine, except the two cases of [BMIM]OTf and [BMIM] $\mathrm{BF}_{4}$ which gave lower yields Table 1. This reflects that the anion exchange agents of [BMIM] based ILs are effective significantly on oxidation of hesperidin. A possible explanation that when an anion group of ILs is replaced by the other anion metathesis, the polarity of ILs could reduce the reaction yields as observed in the case of [BMIM]OTf and [BMIM] $\mathrm{BF}_{4}{ }^{19}$

Table 1. Reaction speed required temperature and yields of diosmin synthesis in various solvents.

\begin{tabular}{ccccc}
\hline Entry & Solvent & $\begin{array}{c}\text { Time } \\
(\mathbf{h})\end{array}$ & $\begin{array}{c}\text { Temperature } \\
\left({ }^{\mathbf{O}} \mathbf{C}\right)\end{array}$ & $\begin{array}{c}\text { Yield* } \\
(\mathbf{\%})\end{array}$ \\
\hline $\mathbf{1}$ & Pyridine & 12 & 90 & 76 \\
$\mathbf{2}$ & {$[\mathrm{BPY}] \mathrm{Br}$} & 6 & 68 & 85 \\
$\mathbf{3}$ & {$[\mathrm{BPY}] \mathrm{BF}$} & 8 & 70 & 85 \\
$\mathbf{4}$ & {$[\mathrm{BPY}] \mathrm{Otf}$} & 6 & 70 & 81 \\
$\mathbf{5}$ & {$[\mathrm{BMIM}] \mathrm{Br}$} & 8 & 70 & 79 \\
$\mathbf{6}$ & {$[\mathrm{BMIM}] \mathrm{Otf}$} & 6 & 70 & 35 \\
$\mathbf{7}$ & {$\left[\mathrm{BMIM} \mathrm{BF}_{4}\right.$} & 6 & 70 & 31 \\
\hline
\end{tabular}

*Ratios of reagents: Hesperidin : Iodine $: \mathrm{NaOH}=1: 1.1: 2$

\subsection{Effect of water concentration on the recyclable solvents the conversion}

ILs are well known recyclable and highly stable reagents. However, these characteristics can be changed in the presence of water absorbed when ILs were exposed to air and moisture. The water content in ILs has a significant influence in the quality and the useful lifetime of the solvents ${ }^{22-23}$

because the ionic liquids are quite different compared with conventional solvents, simply they cannot be easily purified by distillation due to their very low viscosity. This can lead to that the small amount impurity can affect the ILs properties significantly.

In this work, the conversion of hesperidin in recyclable ILs was investigated in the presence of various water concentrations ranging from $1 \%$ to $45 \%$ Figure 3. For comparison, two ILs, [BPY]Br and [BMIM] Br were selected to study the influence of water on the recyclability to compare with pyridine, a common solvent in the analogous conditions. The results indicated that the yield of diosmin in pyridine as a solvent climbed slightly up in the presence $1 \%$ of water. However, this trend changed when the concentration of water rose over $1 \%(\mathrm{v} / \mathrm{v})$. Most notably, the presence of water in $[\mathrm{Bmim}] \mathrm{Br}$ and $[\mathrm{BPY}] \mathrm{Br}$ reduced sharply the yield of diosmin. On the other hand, a tiny content of water $(1 \%, \mathrm{v} / \mathrm{v})$, it induced a significant increase in the yield from $76 \%$ to $90 \%$. By purposely adding more water into the pyridine, the total required volume of pyridine for diosmin synthesis can be reduced but still maintain high production. Whereas, the increase of water content in pyridine caused a steady reduction in the conversion efficiency and the lowest yield $23 \%$ was obtained at $45 \%$ of water content $(\mathrm{v} / \mathrm{v})$. In comparison with the ILs, it was found that the content of water at any tested concentration in the ILs led to a rapid decrease in the yields. With the water concentrations in [BMIM] $\mathrm{Br}$ and [BPY] $\mathrm{Br}$ in the range of $1 \%$ to $45 \%$, rapid reduction in yields $39 \%$ to $7 \%$ and from 28 to $6 \%$, respectively, were observed by HPLC measurements. Such changes were explained due to influence on the water to the polarity of pyridine and ILs. This was explained in the synthesis procedure of diosmin, thus water should be avoided in all solvents. 
Oxidation of hesperidin into diosmin using ionic liquids

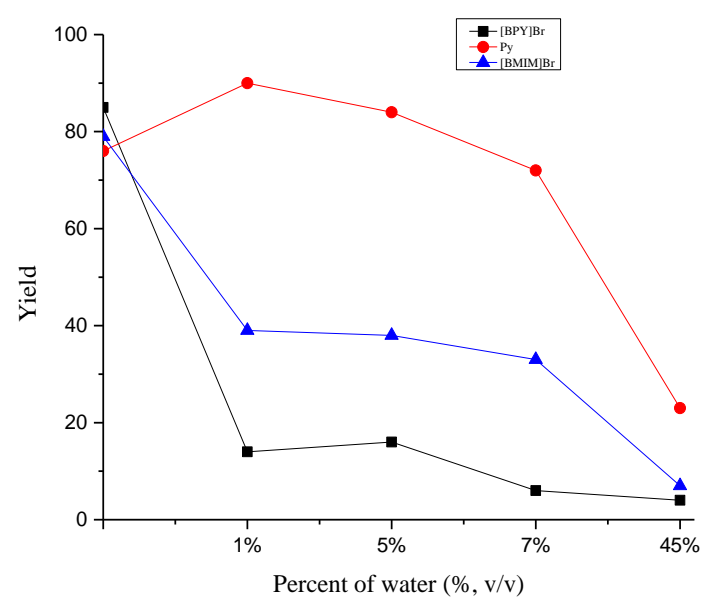

Figure 3. Effect of the water concentration on the synthesis of diosmin

\section{Conclusion}

In this paper, we report for the first time the synthesis of diosmin through the oxidation off hesperidin with iodine in ionic liquids medium. The experimental results showed that using ILs in substitute for traditional organic solvent pyridine allows higher diosmin yield, up to $85 \%$, and is more environmentally friendly since ILs can be recovered after the reaction for further use, significantly lessen the amount of organic waste during the whole synthesis process. High yield of diosmin was still achievable with recycled ILs, however, water contaminant should be kept at a minimum during the recovery process to avoid a reduction in production yield.

\section{ORCID}

V. Thanh Nguyen :0000-0003-4258-2187

Kim-Chi Huynh: 0000-0002-6214-8022

Thanh-Danh Nguyen:0000-0001-6330-8916

T. Kim-Dung Hoang: $\underline{0000-0002-9369-8051}$

\section{References}

[1] Garg, A.; Garg, S.; Zaneveld, L. J. D.; Singla, A. K. Chemistry and pharmacology of the citrus bioflavonoid hesperidin. Phytother. Res. 2001, 15(8), 655-669.

[2] Parhiz, H.; Roohbakhsh, A.; Soltani, F.; Rezaee, R.; Iranshahi, M. Antioxidant and anti-inflammatory properties of the citrus flavonoids hesperidin and hesperetin: an updated review of their molecular mechanisms and experimental models. Phytother. Res. 2015, 29(3), 323-331.

[3] Jain, M.; Parmar, H. S. Evaluation of antioxidative and anti-inflammatory potential of hesperidin and naringin on the rat air pouch model of inflammation. Inflamm. Res. 2011, 60(5), 483-491.

[4] Carvalho, O. V.; Botelho, C. V.; Ferreira, C. G. T.; Ferreira, H. C. C.; Santos, M. R.; Diaz, M. A. N.; Júnior, A. S. In vitro inhibition of canine distemper virus by flavonoids and phenolic acids: implications of structural differences for antiviral design. Res. Vet. Sci. 2013, 95(2), 717-724.

[5] Salas, M. P.; Céliz, G.; Geronazzo, H.; Daz, M.; Resnik, S. L. Antifungal activity of natural and enzymatically-modified flavonoids isolated from citrus species. Food Chem. 2011, 124(4), 1411-1415.

[6] Thenmozhi, A. J.; Raja, T. R. W.; Janakiraman, U.; Manivasagam, T. Neuroprotective effect of hesperidin on aluminum chloride induced Alzheimer's disease in Wistar rats. Neurochem. Res. 2015, 40(4), 767-776. 
Nguyen et al., Org. Commun. (2019) 12:2 101-108

[7] Dobiaš, L.; Petrová, M.; Vojtko, R.; Kristová, V. Long-term treatment with hesperidin improves endothelium-dependent vasodilation in femoral artery of spontaneously hypertensive rats: The involvement of NO-synthase and Kv channels. Phytother. Res. 2016, 30(10), 1665-1671.

[8] Roohbakhsh, A.; Parhiz, H.; Soltani, F.; Rezaee, R.; Iranshahi, M. Neuropharmacological properties and pharmacokinetics of the citrus flavonoids hesperidin and hesperetin-a mini-review. Life Sci. 2014, $113,1-6$.

[9] Maksimovic, Z. V.; Maksimovic, M.; Jadranin, D.; Kuzmanovic, I.; Andonovic, O. Medicamentous treatment of chronic venous insufficiency using semisynthetic diosmin-a prospective study. Acta. Chir. Iugosl. 2008, 55(4), 53-9.

[10] Monography. Diosmin-Monograph.; Alternative medicine review; Thorne Research 2004, 3, 308 -311.

[11] Hodek, P., Trefil, P.; Stiborová, M. Flavonoids-potent and versatile biologically active compounds interacting with cytochromes P450. Chem.-Biol. Interact. 2002, 139(1), 1-21.

[12] Queenthy, S. S.; John, B. Diosmin exhibits anti-hyperlipidemic effects in isoproterenol induced myocardial infarcted rats. Eur. J. Pharmacol. 2013, 718, 213-218.

[13] Pari, L.; Srinivasan, S. Antihyperglycemic effect of diosmin on hepatic key enzymes of carbohydrate metabolism in streptozotocin-nicotinamide-induced diabetic rats. Biomed. Pharmacother. 2010, 64(7), 477-481.

[14] Gopalakrishnan, V.; Iyyam Pillai, S.; Subramanian, S. P. Synthesis, spectral characterization, and biochemical evaluation of antidiabetic properties of a new zinc-diosmin complex studied in high fat diet fed-low dose streptozotocin induced experimental type 2 diabetes in rats. Biochemistry research international 2015.

[15] Cremades, Francisco Javier López. "Process for the preparation of diosmin." U.S. Patent Application No. 15/544,174.

[16] Raijv, S.; Manmohan, N.; Navin, K.; Subarao, P.; Santosh, B.; Ranjendra, P. "Process for the preparation of diosmin", International Application Published Under The Patent Cooperation Treaty (PCT), Patent WO 2010/092592 A2, 1-12.

[17] Hoang, T. K. D.; Huynh, T. K. C.; Nguyen, T. D. Synthesis, characterization, anti-inflammatory and anti-proliferative activity against MCF-7 cells of O-alkyl and O-acyl flavonoid derivatives. Bioorg. Med. Chem. 2015, 63, 45-52.

[18] Hoang, T. K. D.; Huynh, T. K. C.; Do, T. H. T.; Nguyen, T. D. Mannich aminomethylation of flavonoids and anti-proliferative activity against breast cancer cell. Chem. Pap. 2018, 72(6), 1399-1406.

[19] Wasserscheid, Peter, and Thomas Welton, eds. Ionic liquids in synthesis. John Wiley \& Sons, 2008.

[20] Loupy, A. Solvent-free microwave organic synthesis as an efficient procedure for green chemistry. $C R$ Chim Chimie 2004, 7(2), 103-112.

[21] Aupoix, A.; Pégot, B.; Vo-Thanh, G. Synthesis of imidazolium and pyridinium-based ionic liquids and application of 1-alkyl-3-methylimidazolium salts as pre-catalysts for the benzoin condensation using solvent-free and microwave activation. Tetrahedron 2010, 66(6), 1352-1356.

[22] Seddon, K. R.; Stark, A.; Torres, M. J. Influence of chloride, water, and organic solvents on the physical properties of ionic liquids. Pure Appl. Chem 2000, 72(12), 2275-2287.

[23] Fioroni, G.; Fringuelli, F.; Pizzo, F.; Vaccaro, L. Epoxidation of $\alpha, \beta$-unsaturated ketones in water. An environmentally benign protocol. Green Chem. 2003, 5(4), 425-428.

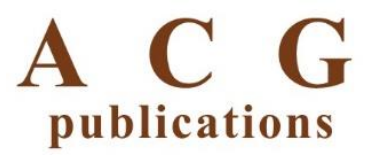

(C) 2019 ACG Publications. 